\title{
THE PARADOX BETWEEN APPEARANCE AND TRUTH IN EPHREM THE SYRIAN'S HYMN DE CRUCIFIXIONE IV
}

\author{
Phil J. Botha \\ (University of Pretoria)
}

\begin{abstract}
The presence and literary function of certain polarities in this particular hymn are investigated. It concerns polarities formed by the contrast between what was visible during the trial and crucifixion of Christ and what was believed by the Christian community who created and used these hymns to be the truth. It is found that Ephrem expressed the polarities in the form of ironic paradoxes. These paradoxes were supposed to strengthen the unity of the Christian community by focusing on the increase in honour of Christ during what seemed to be a process of shaming him.
\end{abstract}

\section{Introduction}

One of the most conspicuous characteristics of the poetry of Ephrem, the Syriac father of the church of the fourth century, is his fondness of polarities. In a random sampling study of hymns from all his cycles, it was found that on average every two lines of poetry in his hymns would contain at least one polar word pair. ${ }^{1}$ Although simple antithetic parallels form the core of these polarities, quite a number of them occur in the form of paradoxes, in other words, logical polarities. According to Rouwhorst, Ephrem has a "grande prédilection pour les paradoxes". ${ }^{2}$ This predilection is also evident in his hymns on Easter and in this particular hymn from that group.

In the fourth hymn from his cycle of hymns on the crucifixion, which forms part of the collection on the feast of Passover, particulars from the passion narrative are interpreted symbolically. ${ }^{3}$ Between some of these details and the symbolic meanings ascribed to them, there exists a relationship which can be described as paradoxical. The "true" or spiritual meaning of these actions are contrasted with what is perceived. ${ }^{4}$

The issue under investigation here is the use of such paradoxes in this particular hymn. Is it a salient feature of this particular hymn? If so, can it be described as an important part of the textual strategy of this hymn? And to what purpose is it used? The author of this paper is also interested in the relationship of these paradoxes with a social value described as "deception", which seems to have 
been important at the time when the books of the New Testament were put into writing. ${ }^{5}$ Its presence and function in this hymn will also be investigated.

For the purpose of this investigation, the hymn will be translated into English. The polarities will be marked in the translation. Afterwards, the polarities that are considered to be paradoxical will be discussed. Bold type and italics are used to mark the opposite poles of polarities, while words underlined with a double line indicate a symbolic relationship between the two. Not all symbolic polarities in this hymn are paradoxical. Ephrem was very fond of symbols from nature. These would usually concern an element from nature, such as the moon or the sun that points towards a spiritual entity such as Christ or his church. ${ }^{6}$ Towards the end of this particular hymn, there are instances of such symbolic interpretation of natural phenomena that occurred at the time of the crucifixion. The polarities and symbolic elements in this hymn that can be described as paradoxical all concern actions of people such as the Jews and Romans during the trial and execution of Christ.

\section{Translation}

Again on the crucifixion

On the melody: The bride of the King

1

My brothers, the slave hit the cheek of the master ${ }^{7}$ who sets the slaves free. Oh, the gentle one who wanted to liberate even that slave who hit him!

The master of the accursed slave was sad that he hit the cheek and thus did not accept his liberation.

A slave that is liberated takes (a blow) on the cheek. In this instance the one who liberates all was struck.

Response: Heaven and also earth and all that are in it are too small to give thanks for this!

Since $[\text { they }]^{8}$ were crazy they clothed him, ${ }^{9}$ they made him king through the royal clothes. ${ }^{10}$

While they were mocking [their Lord] ${ }^{11}$ like an idiot ${ }^{12}$, they symbolically worshipped him.

Through the crown of thorns which they laid on him they showed and testified that he removed the curse of Adam. ${ }^{13}$ 
In everything through which they wished to deny his words his truth was crowned by the liars.

\section{3}

We hear that they entered and brought out the cover of the altar.

They searched intensely for a cause to accuse him. To throw the sign of kingship on him

they entered and uncovered the holy altar

and clothed him so that he would die. ${ }^{14}$

Together with the coverings of the holy place he took the kingship like the Ephod with which also David clothed himself. ${ }^{15}$

\section{4}

An ordinary man who touched the altar or its instruments would certainly die. ${ }^{16}$

"According to our law", they said, "he deserves death". ${ }^{17}$ And so that they would not be sentenced

by the kingship that conquered them,

they did not give this reason why they clothed him:

they were afraid to reveal it.

They cunningly accused because they were afraid.

5

For they wanted to lay two snares for him who examines everything.

They cunningly cast on him the sign of kingship

and they cast on him the garment of glory ${ }^{18}$

so that he would through one or the other

be delivered to death. Since they wanted to besiege him through two

things

he besieged them through two things by taking the kingship and the priesthood.

6

Upon this they handed him over to the judge without realising that they would be condemned by him.

The curtain prophesied through the voice ${ }^{19}$ of its tearing the final destruction. ${ }^{20}$

While they conquered the conqueror, they were thoroughly conquered. Their guilt was the cause of the destruction. 
Who has seen a master whose slave sat to judge him and then write, attach ${ }^{21}$ (the judgement with nails), and announce his kingship!

\section{7}

The Caesar whom the accusers chose, demolished their place of living. What is more, that judge upon whom they called to hand him over to them: The bribe did not blind the just one, for he declared the innocent one to be innocent and he became an accuser of the scribes.

With water he washed his hands ${ }^{22}$ from that living blood, since the house of Cain defiled him together with their nation.

8

They gave a pledge to one another in all generations, one generation to the other

for they feared because they sensed that the guilt was full of wrath.

But when they were divided, one generation was not willing that the other should escape.

They were like a gang of robbers who betrayed one another, they resembled murderers who were judged and found guilty but were not willing that their colleagues be saved. ${ }^{23}$

9

And when they shouted against him and scourged him, they did not realise that he would repay the punishment ${ }^{24}$

of that owner who was laid waste and who sinned in Eden.

Oh, to you, the Lord who had compassion for his slave ${ }^{25}$ so that he would not be scourged,

and presented his son and (had him) scourged in his place.

Heaven and earth and everything that are in it are too small to give thanks for this!

10

And at the pillar to which they led him, they displayed the symbol of the downfall of the people.

It was not like Samson who was bound and pulled down the columns.

The Lord of Samson is himself the true pillar

of the holy city: he let go of her and she fell. 
The Chaldeans destroyed it, but they erected it again.

Since she renounced her pillar, she was demolished (completely). ${ }^{26}$

11

By scourging him with lashes they formed a symbol of their own suffering through his suffering.

For he took away the kingship and the priesthood and the prophecy.

For he plucked out and took the three ribs

from the mouth of the wild animal. ${ }^{27}$

Her horns ${ }^{28}$ he broke and her rib he removed and threw away.

Her power he took from her and it was shattered.

The veil that was rent ${ }^{29}$ was a cry of mourning against the sanctuary, it was a cry of wailing since it would be demolished and abandoned in this time.

That he tore his tunic ${ }^{30}$ was a symbol of the priesthood, for the true Priest came and put it on.

The sanctuary tore its veil. That is a symbol that he would put it on and also (take over) the altar of the sanctuary for his service.

13

The earth that shook pointed to the destruction of their houses.

And that their foot shook, to remove them it rejected them

and threw them in the four directions

and made them dispersed ones through wrath:

the people who were dispersed so that the peoples could be assembled.

The temple is destroyed and our sanctuary is built.

14

That sun also, the lamp of mankind, extinguished itself.

He took the veil of darkness and spread it out before his face

so that he would not see the shame of the Sun of righteousness ${ }^{31}$

in whose light the angels from above shine.

Creation staggered and heaven inclined.

Sheol vomited the dead people and spat them out.

15

The stars also served him on the day of suffering. 
All of them were full, a symbol of his fullness in which there is no deficiency.

The sun showed the symbol of his (divine) glory, the moon showed the symbol of his humanity; both proclaimed him. At the break of day, the moon saw the sun opposite it, the symbol of his flock coming towards him.

\section{6}

Furthermore, the grave in which they laid him down was new, ${ }^{32}$ for it was symbolic of the peoples that were baptised and washed and purified and made new. And body and blood, a symbol of the death of the king they mix in love within their bodies.

On the third day he rose and left the grave:

his death that is in us life for evermore.

17

The rock of his grave that the angel from above rolled away is like a slave that opens the door with respect before his master. Three angels ${ }^{33}$ they saw by his grave: that he would be raised on the third day the three of them proclaimed. Mary ${ }^{34}$ who saw him is a symbol of the church that will be the first to see the sign of his coming.

18

His linen garments ${ }^{35}$ also proclaim his way of life that shines brightly for that darkness could not conquer him.

The garments that were in the grave remained there, but the body did not remain

so that his body would proclaim the resurrection of the bodies.

The embalming of his body was a symbol of the true word for it preserves the lives of the souls.

\section{Analysis of polarities and paradoxes}

One of the most basic polarities in this hymn, in the sense that it forms the substructure for a number of other polarities, is that between the Jewish nation and the church. In terms of a social-scientific analysis, the in-group and the outgroup are very easily identified in the whole collection of hymns on Easter. In 
this hymn, for instance, the Christian community is addressed as "my brothers" $\left.\left(y x^{*}\right)\right)$ at the beginning of Stanza 1. The Jews are mostly referred to with third person masculine plural forms: "they" and "their". Similarly the in-group features as "we", for instance at the beginning of Stanza 3: "We hear that they..." In one instance the contrast between the Jews and the Church is expressed in the terms that Ephrem was so fond of: the "people" and the "peoples", referring to the Jews and the people from all nations who have replaced them (Stanza 13). The Jews are also referred to in yet another stanza as "the people" (Stanza 10) and the Church as "the peoples" in Stanza 16.

From this hymn - as with most of the others in the cycle - it is clear that there was a bitter enmity between Jews and Christians in the time of Ephrem. The Jews (the contemporaries of Jesus) are described as being "crazy" (Stanza 2). They are made out to be "liars" (Stanza 2). Some of the things that they have done according to this hymn are not described in the Gospels as being their actions, but rather those of the Roman soldiers. Such instances have been noted in footnotes at the translation above. In all fairness, it may be presumed that Ephrem was indeed aware of the difference between what the soldiers did to Christ and what the Jewish leaders did to him, but that he deliberately chose to interpret the deeds of the Roman soldiers as the direct result of the Jews' antagonism against Jesus. This is a possible solution, since Ephrem does acknowledge the apocryphal nature of the story about the Jews having gone into the temple and having removed the cover of the altar. He does this by explaining, "We hear that..." (Stanza 3). ${ }^{37}$

Nevertheless, there is no justification for the unkind things that Ephrem says about the Jews, for instance that they resembled a gang of robbers and murderers and that a particular section of their group was unwilling to let others go free when they themselves were found guilty. He also calls them "the house of Cain that defiled" the hands of Pilate (Stanza 7). It is clear that there was a vehement opposition between Jews and Christians. ${ }^{38}$ One may ask what the origin of this kind of anti-Judaism was. Numerous answers have been given to this question, ${ }^{39}$ but perhaps one more possibility can be added. It may be contended that it was an attempt to strengthen group cohesion within the Christian community. Like almost all religious writings, these hymns are ideological documents. They aim not only to please, but also to inform, to convince, and to advance group cohesion. As was the case in the time of the New Testament, there is a strong dyadic ${ }^{40}$ perspective and group cohesion visible in the hymns on Easter. 
It is contended here that the paradoxes, as is the case with the majority of polarities in this hymn, serve to defend the honour of God as he was defined in the Christian tradition. The apostle Paul wrote to the Corinthians that the Jews regarded the crucified Christ as something offensive (a skandal on) but that Christ is the power of God and the wisdom of God (1 Cor 1:23-24). These words, which also contain a paradox, may serve as a summary of the contents of this hymn. The paradoxes in it can mostly be described as "ironic" paradoxes in the sense that the events that combined to form the Via Dolorosa have a significance that is hidden and quite the opposite of what would be understood by someone who does not have a spiritual vision. The paradoxes are typically constituted when actions of the Jews are described as having the opposite effect of what was intended. What the Jews attempted to do, namely to deny the claims made by Jesus and to shame and neutralise him, had the opposite effect of substantiating his claims and aiding the course of action that was predetermined by God. In a certain sense the paradoxes thus serve to preserve the honour of Christ and to promote the honour of the Christian community who worshipped him as the true Messiah.

The first stanza of this hymn contains a polarity, but not such a distinct paradox. The servant of the High Priest who hit Jesus in the face is described as a "slave" who hit the cheek of the "master" who sets the slaves free. Ephrem had the idea that the liberation of a slave in biblical times involved his or her being struck on the cheek. ${ }^{41}$ The antonyms "master" and "slave" form a polarity while the action of the slave striking the master has a paradoxical ring (the act and the fact that it is tolerated, is in conflict with what one would expect). The feeling is strengthened when we learn that this particular master is the one who liberates all and that, to liberate this slave, it was necessary for him to strike the slave, not the other way round. In this way the benevolence of the master, Christ, is highlighted. He, who is the master that liberates everyone, accepted this disgrace for the sake of submission to the will of God. Ephrem himself gives an indication that this was the intended meaning of the stanza by describing Christ as "the gentle one who wanted to liberate even that slave" and who was "sad" that the slave did not accept his own liberation.

In the subsequent stanzas, similar actions by the Jews, which were meant to harm and humiliate Jesus, are described as ironic paradoxes that achieved the opposite of what was intended. In the second stanza, for instance, it is described how the Jews (sic) clothed him with royal clothes and mockingly worshipped him. They also crowned him with a crown of thorns. These actions, it is then stated, were intended to "deny his words". Instead they had the effect 
of "crowning" his "truth". By using the word "crown" for the idea of confirming the truth, a second polarity is created. The crown of thorns is first juxtaposed with the thorns mentioned in the curse of Adam by God. According to Genesis 3:18, the ground was cursed and would produce thorns for Adam. By putting a crown of thorns on the head of Jesus, the attempt to humiliate him became a symbol of his removing the curse of thorns pronounced on Adam. Second, their action of crowning Jesus also became a symbol of endorsing the truth of his claims to be the Son of God. But they did not realise this, therefore the reversed results of their actions constitute an ironic paradox. In this instance, the paradox is once again between what is perceived by the instigators of the actions and the truth that is perceived by those who have spiritual insight. The link between the two worlds is described by such words as "symbolically" and "they showed and testified" and "his truth was crowned".

In the third stanza, more detail is given on the attempt to mock Christ by clothing him with royal clothes. The Jews are reported, according to a tradition not found in the Gospels, to have entered the temple and to have removed the covering of the altar and to have used this as a royal cloak with which they wanted to humiliate Christ. They also had more evil intentions, since they wanted to kill him by doing this. It was well known that only the priests had the right to touch the altar and its instruments. ${ }^{42}$ What they did therefore constitutes attempted murder. They did, however, not voice this reason. They "cunningly" (and secretly) planned what can be described as "a fork", an attack on two fronts. But this had a particularly negative effect on them, since Christ "accepted" the kingship thus bestowed upon him, while he also "took away" the priesthood (Stanza 5). They received a double blow so that the intention of their actions is balanced by the results. But since they did not realise this, it also constitutes an ironic paradox.

The intended function of this paradox seems to be to draw attention to the paradoxical nature of the truth hidden within the events that took place during Jesus' last hours, but hinted at by the events themselves. The result is that the humiliation of Christ is not seen as such by believers, but as a series of witnesses to the spiritual reality of his being honoured by God. This reality is perceivable through the eye of faith. ${ }^{43}$

The same is true for a series of similar ironic paradoxes that follows. Jesus was turned over to a judge to have him condemned, but it resulted in their own condemnation (Stanzas 6 and 7). The pillar to which Jesus was bound in order 
for them to scourge him, becomes a symbol of Christ who was himself the "pillar" of Jerusalem and who let go of the city of Jerusalem so that she would be demolished (Stanza 10). The high priest who tore his tunic becomes a symbol of the removal of the priesthood from the Jews and the transfer of this to Christ (Stanza 12). In one instance, Ephrem uses a question that often marks the presence of a paradox in his hymns: In Stanza 6 he asks: "Who has seen a master whose slave sat to judge him and ... announce his kingship!" In the same stanza, there is also a logical paradox: "While they conquered the conqueror, they were thoroughly conquered".

The last part of the hymn contains a lot of symbolic polarities, but fewer and fewer paradoxes. It seems that the paradoxes are confined to the description of actions of the Jews. All of these were meant, according to Ephrem, first and foremost to humiliate Christ. There are a number of words from the semantic fields of honour ${ }^{44}$ and shame ${ }^{45}$ and the actions described are known from other biblical contexts to be signs of humiliation. In every instance where a paradox is encountered, the effect is the same: instead of the intended humiliation of Christ, the actions resulted in the humiliation of the Jews and the paradoxical glorification of Christ.

The paradoxes and their contents can be summarised as follows:

\begin{tabular}{|l|l|}
\hline $\begin{array}{l}\text { Actions of the Jews and the } \\
\text { intended result }\end{array}$ & $\begin{array}{l}\text { The true result visible through } \\
\text { faith }\end{array}$ \\
\hline $\begin{array}{l}\text { The Jews made Christ king through } \\
\text { clothing him with royal clothes; they } \\
\text { mocked him; and crowned him with } \\
\text { a crown of thorns to deny his words }\end{array}$ & $\begin{array}{l}\text { They unknowingly accepted his } \\
\text { king hip and symbolic ally } \\
\text { worshipped him; they confirmed his } \\
\text { function of removing the curse of } \\
\text { Adam; and crowned his truth }\end{array}$ \\
\hline $\begin{array}{l}\text { They covered Christ with the veil of } \\
\text { the altar to accuse him of claiming to } \\
\text { be king and to kill him }\end{array}$ & $\begin{array}{l}\text { They did not realise that he would } \\
\text { take the kingship like David took the } \\
\text { Ephod and clothed himself with it; } \\
\text { that he would not be killed by it }\end{array}$ \\
\hline $\begin{array}{l}\text { They cast on him the sign of kingship } \\
\text { and the garment of glory to ensnare } \\
\text { and kill him in one of two ways }\end{array}$ & $\begin{array}{l}\text { They did not realise that he would } \\
\text { return the compliment by taking both } \\
\text { kingship and priesthood from them }\end{array}$ \\
\hline
\end{tabular}




\begin{tabular}{|l|l|}
\hline $\begin{array}{l}\text { They handed him over to the judge to } \\
\text { be condemned }\end{array}$ & $\begin{array}{l}\text { They did not realise that they were } \\
\text { themselves being condemned by the } \\
\text { judge }\end{array}$ \\
\hline $\begin{array}{l}\text { A master is subjected to a trial by his } \\
\text { slave }\end{array}$ & $\begin{array}{l}\text { The master is acknowledged to be } \\
\text { king }\end{array}$ \\
\hline $\begin{array}{l}\text { They shouted against him and had } \\
\text { him scourged }\end{array}$ & $\begin{array}{l}\text { They did not realise that God had } \\
\text { compassion for the "slave" } \\
\text { (mankind) and had his Son scourged } \\
\text { in the place of the slave to repay } \\
\text { Adam's guilt }\end{array}$ \\
\hline $\begin{array}{l}\text { They led him to a pillar like Samson } \\
\text { was led to the two pillars }\end{array}$ & $\begin{array}{l}\text { They did not realise that, unlike } \\
\text { Samson, Christ himself was their } \\
\text { pillar without whom the city of } \\
\text { Jerusalem would be demolished }\end{array}$ \\
\hline They scourged him with lashes & $\begin{array}{l}\text { They unknowingly symbolised their } \\
\text { own suffering: he took away } \\
\text { kingship, priesthood, and prophecy } \\
\text { (prefigured by the animals in the } \\
\text { book of Daniel) }\end{array}$ \\
\hline The High Priest tore his tunic & $\begin{array}{l}\text { He unknowingly symbolised the } \\
\text { removal of the priesthood, since the } \\
\text { true Priest came to put it on }\end{array}$ \\
\hline
\end{tabular}

\section{Conclusion}

It seems that the surmise was correct. There is a polarity between what is perceived by the Jews during the trial and execution of Jesus and what is perceived by believers (who read about these actions) to be the true state of affairs. This polarity is expressed in the first half of the hymn time and again in the form of an ironic paradox. The use of paradoxes can therefore be described as a major textual strategy in this hymn, the purpose of which was to restore the balance of honour that was disturbed through the humiliation and execution of Christ. ${ }^{46}$ What he has suffered was not shameful, but honourable. For this he is praised in a hymn ${ }^{47}$ that puts his suffering in perspective. Next to the human perspective of what happened to Christ, namely a humiliating death, there is also the divine perspective, the truth of his triumph. These two perspectives are 
linked by a kind of symbolic connection. What is visible contains a pointer to the hidden truth that is only visible to the enlightened eyes of believers.

But the polarities and paradoxes where the Jews are involved also have another function. That is to make it quite clear that, by their own doing, the era of the Jews has passed. The institutions of the Old Testament such as prophecy, priesthood, and kingship have been terminated. Christ (and through him the community of Christians) have taken over these functions. The era of the Church has arrived. ${ }^{48}$

Finally, it should be noted that the abundance of contrasts, polarities, and paradoxes in Ephrem's work does not mean that he perceived the world as being full of contradictions. On the contrary, his ability to see the symbolism of practically every word in Scripture and every detail of creation is a clear indication that, for him, every conceivable aspect of reality is interconnected to form one complete and meaningful whole. ${ }^{49}$

\section{NOTES}

1. P.J. Botha, unpublished research report "Polêre strukture in die himnes van Afrem die Siriër: Hulle konstruksie en funksie”, University of Pretoria, 1991, p.12.

2. G.A.M. Rouwhorst, Les hymnes Pascales d'Ephrem de Nisibe, (Analyse théologique et recherche sur l'évolution de la fête pascale chrétienne à Nisibe et à Edesse et dans quelques Eglises voisines au quatrième siècle), I Etude, Leiden, Brill, 1989, p.39.

3. Ephrem does not provide a systematic or chronological treatment of the passion narrative, but rather works in an associative way, focussing on an episode, a person, or an object that is mentioned in the New Testament (Rouwhorst, Les Hymnes Pascales, I Etude, p. 93).

4. The polarity between the hidden and the revealed is frequently encountered in the works of Ephrem. Usually it indicates the perception that God is hidden to mankind except for those instances when he reveals something of himself. What is hidden is often called "truth" in these contexts. Cf. in this regard S. Brock, The luminous eye, the spiritual world vision of Saint Ephrem the Syrian, Cistercian Publications 1992, pp.27-28. In this hymn, however, "truth" does not primarily refer to the reality of the existence of God. It is therefore better to speak of the polarity between "appearance" and "truth" rather than "hidden" and "revealed". This polarity is closely linked to the polarity between the divinity and humanity of Christ, a contrast which, as Rouwhorst puts it, "qui atteignit son paroxysme au moment de la passion et 
de la mort du Seigneur" (Rouwhorst, Les Hymnes Pascales, I Etude, p. 96).

5. It refers to the view that appearances can be misleading. Neyrey (J.H. Neyrey, "Deception", article in J.J. Pilch \& B.J. Malina, Handbook of Biblical Social Values, Hendrickson 1998, pp. 40-45) refers to 1 Cor 1:23-25 as an example: "the crucified Christ appears foolish and weak to the Jew and the Greek, but in truth he is God's wisdom and strength", p.41. This context happens to be very relevant for this particular hymn. Deception is seen as a means value in the world of the Bible. It was a strategy for establishing and protecting honour and for bringing shame upon one's enemies (Neyrey, p.43).

6. Cf. Rouwhorst, Les hymnes Pascales (I Etude), p.69. Brock speaks of a "sacramental character of the created world" in this regard. The exterior, physical realm is connected with an interior, spiritual realm that can only be seen by the eye of faith. Cf. S. Brock, Saint Ephrem, Hymns on Paradise, St Vladimir's Seminary Press (New York), 1990, p.39.

7. Cf. John 18:22 which uses the same words (without the preposition) and which is the context referred to according to Edmund Beck, Des Heiligen Ephraem des Syrers Paschahymnen (De Azymis, De Crucifixione, De Resurrectione), Übersetzungen, CSCO Vol. 249, Tome 109, Peeters, Leuven, 1964, p.44, n.2. As Rouwhorst (G.A.M. Rouwhorst, Les hymnes Pascales d'Ephrem de Nisibe, II Texte, Leiden, Brill, 1989, p.61, n.1 observes, not one of the Syriac translations use the term "slave" ()dB(), but always speak of the "guard" or "attendant" ()\$Xd). He thinks that Ephrem possibly thought of the "servant" ( $) \mathrm{dB}()$ of the High Priest mentioned in a number of contexts (Matthew 26:51; Mark 14:47; Luke 22:50; and John 18:10).

8. The plural form of the participle is uncertain. Cf. Edmund Beck, Des Heiligen Ephraem des Syrers Paschahymnen, Texte, CSCO Vol. 248, Tome 108, Peeters, Leuven, 1964, p.55, n.2.

9. Clothing was of great social importance, since clothes indicated role and status in society, thus honour or lack of honour. To clothe someone would therefore mean to assign honour to someone. In this case, the act of clothing Christ was an ironic attempt at shaming him. But the effect was indeed to confer honour upon him. That is why the Jews (who were responsible for this act according to Ephrem) are described as being crazy. Cf. the article by J.H. Neyrey on "Clothing" in Pilch \& Malina, op. cit. 1998, pp. 21-27.

10. Ephrem transposes what is said in the gospels (cf. Matthew 27:28; Mark 15:17; John 19:2) of the Roman soldiers to the Jews.

11. The reading is uncertain.

12. The reading of the text is uncertain.

13. Cf. the thorns mentioned in Genesis 3:18. Cf. also Ephrem's comment on this in his commentary on the Diatessaron. Translation consulted in $\mathrm{C}$. MacCarthy, Saint Ephrem's Commentary on Tatian's Diatessaron. An 
English translation of Chester Beatty Syriac MS 709 with introduction and notes. Oxford (University Press), 1993, p.302.

14. The same tradition is also mentioned in the hymns De Azymis IV.6.

15. Cf. 2 Sam. 6:14.

16. Rouwhorst (Les Hymnes Pascales, II Textes, p. 62, n.9 thinks that this is probably an allusion to Numbers 4:15 and 20. He also notes that the Syriac word used for "instruments" or "utensils" can also mean "clothing".

17. Cf. John 19:7.

18. The choice of words is very significant. Ephrem often uses clothing imagery with the "robe of glory" to indicate the Fall of man, the incarnation of Christ, the new status obtained by believers at baptism, and the resurrection of the dead. In this instance, the text seems to hint at the glorification of Christ who returns to his divine status. Cf. also S. Brock, Saint Ephrem hymns on Paradise, 1990, p.67. As Rouwhorst (Les Hymnes Pascales, II Textes, p.62 n.12) notes, the two snares were implicating him to have claimed that he is king and that he is God. This is also made clear by Ephrem's commentary on the Diatessaron. Cf. C. McCarthy, op. cit., pp. 301-302.

19. Rouwhorst (Les Hymnes Pascales, II Textes, p.63, n.15) comments: "Le déchirement du rideau du temple (Matth. 27,51; Mc. 15,38) est attribué à la voix du Seigneur qui crie, en mourant (Matth. 27,50; Mc. 15,37; Luc. 23,46).

20. The destruction of Jerusalem (and the temple) in A.D. 70.

21. Beck (Paschahymnen, Übersetzungen, op.cit., p.45 n.10) cites John 19:19 although the vocabulary differs between the two contexts.

22. The wording is that from Matthew 27:24.

23. Matthew 27:25.

24. The words for "scourge" and "punishment" come from the same Syriac root (dGN and )dGN).

25. Adam.

26. Rouwhorst (Les Hymnes Pascales, II Textes, p.64 n.24) thinks that this is possibly an allusion to the attempts of the Jews to restore the temple during the reign of Julian.

27. Daniel 7:5.

28. As Beck (Paschahymnen, Übersetzungen, p.46 n.13) notes, in Daniel this is not the same visionary animal.

29. Beck (Paschahymnen, Übersetzungen, p.46 n.12) refers to the description in Matthew 27:51 and parallels.

30. Mark 14:63.

31. Cf. Malachi 3:20 (MT).

32. Matthew 27:60 and parallels.

33. According to Beck (Paschahymnen, Übersetzungen, p.47 n.22) the number three was calculated by adding the one angel mentioned in Matthew 28:2 (so also Mark 16:4) to the two mentioned in Luke 24:4 and John 20:12. So also Rouwhorst (Les Hymnes Pascales, II Textes, p.65 n.35). 
34. According to Beck (Paschahymnen, Übersetzungen, p.47 n.23), Mary the mother of Jesus is meant since she is often depicted as a symbol of the church. Robert Murray, Symbols of Church and Kingdom, a study in early Syriac tradition (Cambridge University Press, 1975) p.146 notes: “...in passages where (Ephrem) speaks of the appearance of the risen Christ to Mary Magdalen ... he often regards it as not the Magdalen but the Virgin to whom Christ appeared in the garden, while several times he seems to confuse them, or rather deliberately run them into one, both Maries acting together as type of the Church. This 'fusion' is not a peculiarity of Ephrem but is found in other Syrian witnesses..."

35. Using the same word as in John 20:7.

36. This polarity is a shared characteristic between the two great Syriac fathers of the fourth century, namely Aphrahat and Ephrem. According to Murray it forms one of the three main themes of typological exegesis in these two authors' work and occurs time and again. Cf. R. Murray, op. cit., pp.41-68.

37. According to Beck, (Paschahymnen, Übersetzungen) p. 9 n.4, the meaning is that the priests gave the veil to the soldiers to add weight to the accusation against Jesus.

38. Rouwhorst (Les Hymnes Pascales, I Etude, p. 100) notes that Ephrem's antiJewish attitude is the most obvious in those sections of these hymns where he treats the humiliation Christ had to suffer shortly before and during his death.

39. Murray (op. cit., p.67) explains the difference in attitude between Aphrahat and Ephrem as the result of differences in their aims of writing, the literary forms they use, their circumstances, and the spirit of each. Aphrahat had more in common with the Jews than with the Mesopotamian pagans among whom he lived. Therefore he uses respectful, persuasive language. Ephrem writes (for the last ten years of his life, in any case) from within the Roman Empire, where the Jews are already a persecuted nation. His writings are, in a certain sense, a theological justification of the official attitude towards the Jews. Cf. in this regard also W.A. Meeks \& R.L. Wilken, Jews and Christians in Antioch in the first four centuries of the Common Era, Scholars Press (for the Society of Biblical Literature), 1978, pp.25-36. According to them (p.25), the new legislation did not yet attack the fundamental rights of the Jewish community. After Julian's reign ended, Christians began to manifest increasing hostility toward the Jews as a result of Julian's use of the Jews against the Christians (p.30). But it is also true that Judaism still was very attractive to outsiders and Chrysostom's homilies against the Jews paradoxically reveal a widespread Christian infatuation with Judaism (p.31).

40. This refers to the idea that individual people are not known or valued because of their uniqueness, but in terms of their dyad, a secondary unit consisting of an aggregate of monads or individuals. This kind of thinking results in the practice of perceiving oneself and others in stereotypes that emphasise role 
and status. Cf. the article "Dyadism" by J.H. Neyrey in Pilch \& Malina, op. cit., pp. 53-56.

41. It is uncertain where this idea originated. In 2 Cor. 11:20 the act of hitting someone in the face and making someone a slave (rather than liberating a slave) is mentioned as similar ways of shaming someone. Hitting someone in the face was definitely a way of shaming that person, as the thoughts of the judge in the parable of the widow (Luke 18:5) clearly show.

42. Cf., for instance, Numbers 18:3.

43. As Brock explains: "The immanence of the holy in this world involves Ephrem in recognizing connections between everything; everything is of significance and has the potential of being a pointer to Christ: all that is required is the eye of faith to see these hidden links." S.P. Brock, Studies in Syriac Spirituality, (The Syrian Churches Series, edited by J. Vellian, vol. 13), Poona, 1988, p.54.

44. Examples are words and phrases such as "master", "too small to give thanks for this", "crowned", "the garment of glory", "kingship", "Oh, to you, the Lord who had compassion...", "the Sun of righteousness", "his fullness in which there is no deficiency", "his glory", "like a slave that opens the door with respect before his master", "his way of life that shines brightly".

45. All the elements of the treatment given to Jesus were intended to humiliate him. These include his being struck in the face, the crowning with a crown of thorns, the mocking obeisance, the investiture with a royal cloak, etc. What has happened to the Jews as a result of their actions are also shameful: the destruction of Jerusalem, the loss of their preferential status with God, etc. The shameful names used to describe the Jews have already been mentioned, namely words such as "robbers", "murderers", "the house of Cain who defiled him", etc.

46. Or, to put it in another way, it serves to define what is honourable within the Christian tradition. There is always a struggle between groups over the definition of honour and shame. This hymn should be read in the light of what Moxnes (H. Moxnes, "Honor and Shame" in R. Rohrbaugh (ed.), The Social Sciences and New Testament Interpretation, Hendrickson (Peabody) 1996, pp.19-40) has said about Paul's praise of the "shame of the cross" in 1 Cor 1:18-31. He said that it is "...an attempt to give a new definition of what was honorable, in defiance of the dominant social elites of the GrecoRoman world and their values" (p.27).

47. There are certain objections to the practice of describing the madraše of Ephrem as "hymns" (cf. K. den Biesen, "Spreken over God bij Efrem de Syriër", Het Christelijk Oosten, 1995, p.8. But the refrain makes it quite clear that there is an element of praise in this poem.

48. Cf. Rouwhorst, Les Hymnes Pascales (I Etude), pp.62-63.

49. G. Rouwhorst, Ephrem de Syrier. Hymnen voor die viering van het kerkelijk jaar. Ingeleid, vertaald en toegelicht. Kok (Kampen), 1991, p.20. 